\title{
Geohazards affecting UNESCO WHL sites in the UK observed from geological data and satellite InSAR
}

Francesca Cigna, Deodato Tapete, Kathryn Lee

Francesca Cigna, Deodato Tapete, Kathryn Lee, "Geohazards affecting UNESCO WHL sites in the UK observed from geological data and satellite InSAR," Proc. SPIE 9688, Fourth International Conference on Remote Sensing and Geoinformation of the Environment (RSCy2016), 96880X (12 August 2016); doi: 10.1117/12.2240768

SPIE Event: Fourth International Conference on Remote Sensing and Geoinformation of the Environment, 2016, Paphos, Cyprus 


\title{
Geohazards affecting UNESCO WHL sites in the UK observed from geological data and satellite InSAR
}

\author{
Francesca Cigna**a ${ }^{\mathrm{a}}$, Deodato Tapete ${ }^{\mathrm{a}}$, Kathryn Lee ${ }^{\mathrm{a}}$ \\ ${ }^{a}$ British Geological Survey (BGS), Natural Environment Research Council (NERC), \\ Nicker Hill, NG12 5GG Keyworth, United Kingdom
}

\begin{abstract}
Geohazards pose significant threats to cultural and natural heritage worldwide. In the UK, only 1 out of 29 UNESCO World Heritage List (WHL) sites has been inscribed on the list of World Heritage in Danger, whilst it is widely accepted that many more could be affected by geohazards. In this paper we set out the foundations of a methodological approach to analyse geological, geohazard and remote sensing data available at the British Geological Survey to retrieve an overview of geohazards affecting the UK WHL sites. The Castles and Town Walls (constructed in the time of King Edward I) in Gwynedd in north Wales are used as test sites to showcase the methodology for geohazard assessment at the scale of individual property also to account for situations of varied geology and local topography across multiproperty WHL sites. How such baseline geohazard assessment can be combined with space-borne radar interferometry (InSAR) data is showcased for the four UNESCO WHL sites located in Greater London. Our analysis feeds into the innovative contribution that the JPI-CH project PROTHEGO 'PROTection of European cultural HEritage from GeOhazards' (www.prothego.eu) is making towards mapping geohazards in the 400+ WHL sites of Europe by exploiting non-invasive remote sensing methods and surveying technologies.
\end{abstract}

Keywords: geohazard, land instability, heritage, UNESCO, coastal processes, flooding, radar interferometry, subsidence

\section{INTRODUCTION}

Geohazards pose significant threats to cultural and natural heritage worldwide [1]. A number of UNESCO World Heritage List (WHL) monuments and sites are affected and impacted by shallow and deep geological and landscape processes including landslides, subsidence, ground collapse, coastal retreat, floods, earthquakes and volcanic activity, some of which influenced, or triggered by, extreme meteorological events, or exacerbated by climate change and anthropogenic interaction.

Only some of the endangered sites are, however, inscribed on the list of World Heritage in Danger [2], which mainly includes sites threatened by armed conflict, accelerated deterioration, calamities and cataclysms, and rapid urban or tourist development.

In the UK, only 1 out of 29 WHL sites has been recognised as in danger (see section 2.1), whilst it is considered that many more could be affected by geohazards (see section 3). Examples include Maritime Greenwich, the Tower of London, Royal Botanic Gardens of Kew, and the Palace of Westminster and Westminster Abbey in Greater London, where natural and anthropogenic land instability processes were recently observed (see section 3.4).

In this work we analyse geological, geohazard and remote sensing data available at the British Geological Survey (BGS) to retrieve an overview of geohazards affecting the UK WHL sites. The Castles and Town Walls (constructed during the reign of King Edward I) in Gwynedd in north Wales are used as test sites to showcase the methodology to assess geohazard and their potential impacts to the designated WHL properties.

Our analysis feeds into the innovative contribution that the collaborative research project PROTHEGO 'PROTection of European cultural HEritage from GeO-hazards' [3] is making towards mapping geohazards in the 400+ WHL sites of Europe by exploiting mainly satellite radar interferometry (InSAR) ground motion data, as well as other non-invasive remote sensing methods and surveying technologies such as Unmanned Aerial Vehicles (UAV) and LiDAR.

* fcigna@bgs.ac.uk; phone +44 115936 3551; fax +44 1159363446

Fourth International Conf. on Remote Sensing and Geoinformation of the Environment (RSCy2016), edited by Kyriacos Themistocleous et al., Proc. of SPIE Vol. 9688, 96990X · (c) The Author(s).

Published under a Creative Commons Attribution CC-BY 3.0 License $\cdot$ doi: 10.1117/12.2240768 
PROTHEGO is funded in the framework of the Joint Programming Initiative on Cultural Heritage and Global Change (JPI-CH) - Heritage Plus [4], under ERA-NET Plus and the Seventh Framework Programme (FP7) of the European Commission. The project is led by the Italian Institute for Environmental Protection and Research (ISPRA) in collaboration with the UK's Natural Environment Research Council (NERC) as represented by BGS, Cyprus University of Technology (CUT), the University of Milano-Bicocca (UNIMIB) and the Geological Survey of Spain (IGME).

Geohazards for the whole set of European WHL sites are analysed by ISPRA during Work Package 1 (WP1): UNESCO cultural heritage and natural hazards at European scale [5], using datasets available homogeneously for the European territory (e.g. European landslide susceptibility map, Peak Ground Accelerations map) to create a baseline layer identifying potential threats to each site. The resulting European-scale scenario is then downscaled to national and local scales through the use of higher resolution datasets available in each country.

BGS, as the national geological survey and the UK's premier earth science centre, oversees the assessment of geohazards for the UK using national datasets depicting geological processes, hazards and indicators of ground instability.

Remotely sensed information on ground stability and motion are gathered through WP2: Harmonisation of PS data and creation of digital factsheets and then combined with geohazard information to identify the most endangered sites across Europe during WP3: Integration of persistent scatterers (PS) and geohazard products and implementation of multicriteria methodology, and WP4: Identification of most endangered sites.

Local scale geological interpretation, advanced modelling and field surveying will be carried out for these sites via WP5: Local scale monitoring and WP6: Local scale investigation and advanced modelling, to determine the causes and the extent of the observed motions and to provide an enhanced understanding of any geological processes affecting the heritage properties. In the UK, this analysis will be done by BGS for the industrial heritage of the Derwent Valley Mills in Derbyshire in central England [6].

\section{UNESCO WHL SITES IN THE UK}

\subsection{Cultural and natural WHL heritage}

There are 29 UNESCO WHL sites in the UK and overseas territories, including 16 in England, 5 in Scotland, 3 in Wales, 1 in Northern Ireland, 1 in both England and Scotland (i.e. the Frontiers of the Roman Empire, also comprising two sections in Germany), and 3 overseas in Bermuda, the Pitcairn Islands and Saint Helena (Figure 1). The first sites were inscribed on the WHL in 1986, whereas the latest in 2015 (i.e. the Forth Bridge).

Of the 29 sites, 24 (i.e. 83\%) are categorised as cultural and 4 (i.e. 14\%) as natural, whereas St Kilda is the only mixed WHL site in the UK. Due to threats to the site integrity from planned urban development projects, in 2012 the Liverpool - Maritime Mercantile City WHL was added by the World Heritage Committee to the List of World Heritage in Danger.

Most UK WHL designated sites consist of single properties represented by a unique spatial entity (polygon), though some properties contain multiple sites that share a common geographical location or cultural heritage.

Among the latter are the extremely well-preserved Castles and Town Walls in Gwynedd in north Wales (Figure 2), constructed by the architect James of St George during the reign of Edward I and considered the finest examples of late $13^{\text {th }}$ century and early $14^{\text {th }}$ century military architecture in Europe.

The UNESCO WHL site comprises the four castles of Beaumaris, Conwy, Caernarfon and Harlech and the attendant fortified towns at Conwy and Caernarfon.

The property boundaries of each castle include the medieval defensive structures (castles and town walls) but not the planned settlements or waterfronts, although these can be considered an extension of the defensive attributes beyond the narrow boundaries along the town walls, as an integral part of their defensive, administrative and economic arrangements. The waterside position contributed to the castle defense and trade.

The essential relationship between the coastal landscapes and each castle today remains intact and, in the case of Conwy and Caernarfon, the intimate interrelationship of castle and town still stands as a striking feature of the present day urban 
landscape [7]. The UNESCO WHL site in Gwynedd is therefore an interesting exemplar of a multi-property heritage site where the properties are not only important in their individuality but also are part of a cultural heritage ensemble.

Although never constituted a significant issue, potential threats to the conservation and integrity of the castles could come from coastal or off-shore development within the setting of the castles, as well as natural coastal processes such as erosion and flooding [7].

\subsection{Geological setting}

The UK is fortunate in possessing a remarkably varied geology within a relatively small area [8]. The rocks that make up Great Britain and Northern Ireland represent a long and complicated history of geological events. They encompass most of the major periods of geological time as well as extremes of climate from desert to glacier.

The UK's UNESCO WHL sites are situated on a broad range of geology types across the country, from the sedimentary rocks such as chalk, sandstones and clays in the south-east, mining-rich heritage areas of the midlands, through to the heavily folded and faulted metamorphic rocks across much of Scotland (Figure 1).
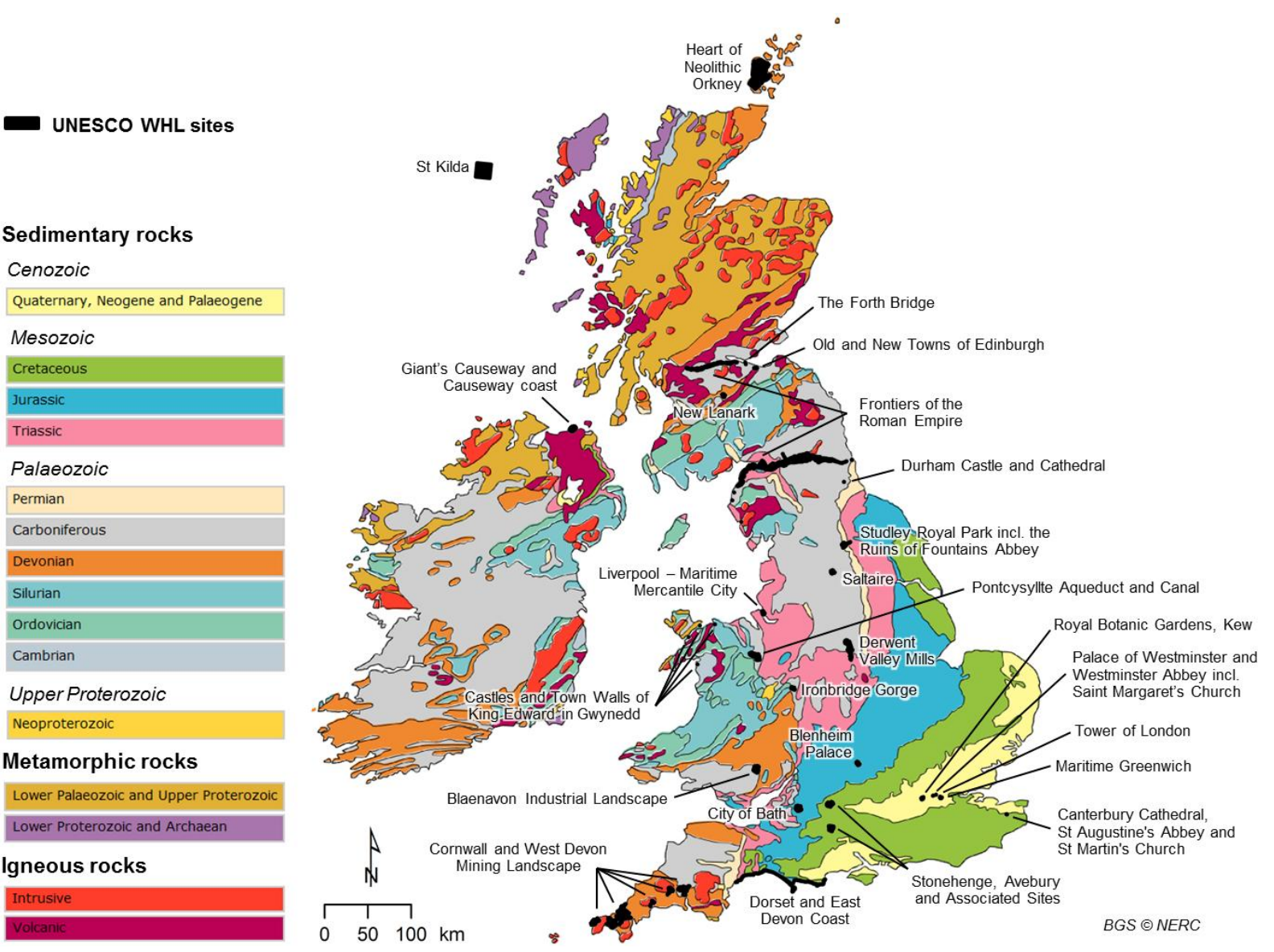

Figure 1. UNESCO World Heritage List (WHL) sites in the UK, overlapped onto simplified bedrock geology of the UK and the Republic of Ireland, the former based on BSG' DiGMapGB [8], [9]. The map does not include the 3 overseas sites of Historic Town of St George and Related Fortifications (Bermuda), Henderson Island (Pitcairn Islands), and Gough and Inaccessible Islands, Tristan da Cunha archipelago (Saint Helena) [Geological materials (C) NERC. All rights reserved; WHL site boundaries: England (c) Historic England 2015; Northern Ireland () ProtectedPlanet 2014-2015. All rights reserved; Scotland: (C) Historic Environment Scotland - Scottish Charity No. SC045925. Contains Ordnance Survey data (C) Crown copyright and database right 2015-2016]. 
North Wales, where the castles of Gwynedd WHL are located, is characterised by rugged mountains and low-lying tracts of alluvial plain. The Ordovician rocks of Snowdonia and the Lleyn Peninsula are predominately sedimentary in origin having undergone repeated earth movements (faulting and folding) and form the higher mountainous ground, surrounded by the eroded coastal plain. There is a widespread covering of till deposits from more recent glacial periods and modern day deposits such as tidal flats and alluvial and estuarine sediments.

Although located at mutual distances of no more than $50 \mathrm{~km}$, the varied regional geology and topography make the four castles rest on different geological and physiographic settings (Figure 2):

- Beaumaris castle (Figure 2a) is located on the northern side of the Menai Straits on the Isle of Anglesey. The castle is underlain by superficial deposits consisting of till, and a bedrock of interbedded Ordovician mudstones and sandstones.

- Caernarfon castle (Figure 2b) is located on the southern side of the Menai Straits. The castle is underlain by interbedded Ordovician mudstones, siltstones and sandstones (LLanvirin Rocks).

- Harlech castle (Figure 2c) sits on a prominent ridge above the coastal plain on the west coast of North Wales. The castle is underlain by the Harlech Grits Group of Cambrian age consisting of interbedded turbiditic sandstones and conglomerates with thin siltstone and mudstones. The coastal plain below the castle is covered by recent blown sand deposits and dunes.

- Conwy castle (Figure 2d) is sited on the south-western edge of the Conwy estuary. The castle is underlain by Ordovician bedrock consisting of interbedded mudstones, siltstones and sandstones (Caradoc Rocks and Ashgill Rocks). Superficial deposits at the site comprise a patchy cover of till and adjacent tidal flat deposits within the estuary.

\section{GEOHAZARD MAPPING}

\subsection{Input datasets}

High resolution $(0.25 \mathrm{~m})$ aerial photographs were used as basemaps for geospatial location of geological and geohazard attributes, while the topography of the castles and the nearby landscape was investigated using $5 \mathrm{~m}$ resolution NEXTMap ${ }^{\circledR}$ Britain digital terrain models [10] and Ordnance Survey (OS) topographic maps at 1:10,000-1:50,000 scales.

Geospatial layers used to characterise the geological constraints and factors that might affect the future preservation of the WHL properties included: Digital Geological Map of Great Britain (DiGMapGB) at 1:625,000 to 1:50,000 scales [11] (Figure 1); Engineering Properties Dataset (DiGMapGB-Plus), in particular Corrosivity [12] and Sulfate and Sulfide Potential [13]; Geological Indicators of Flooding (GIF) [14]; Susceptibility to Groundwater Flooding (GWF) [15]; GeoSure dataset [16], [17], [18].

The latter is a ground stability dataset developed at BGS to identify areas of potential susceptibility with regard to the following six geohazards: (i) shrink-swell of swelling clays that might cause ground movement particularly in the upper two metres of the ground [19]; (ii) slope instability (e.g. landslides, rockfalls) [20]; (iii) ground dissolution of soluble rocks that might develop into underground cavities and generate sudden collapses of the above-ground surface [21], [22]; (iv) compressibility of ground containing layers of very soft materials that may compress if loaded by overlying structures or as a consequence of groundwater level changes; (v) collapse of deposits, especially when saturated; and (vi) loosely packed sandy layers that can fluidised by water flowing through them causing instability to overlying structures (i.e. running sand). Susceptibility is classified using an A (lowest) to E (highest) rating for each of these six geohazard types.

Similar susceptibility rating applies to GWF data, but in this case class "A" indicates limited potential for groundwater to occur, "B" those areas where property situated below ground might be flooded during periods of extended intense rainfall, and "C" those where groundwater flooding can occur at surface. 'Not applicable' class applies to rock types not considered to be prone to groundwater flooding. 
Given that three of the four castles are situated along or close to the shoreline (Figure 2), BGS' GIF dataset was used to assess geological proneness of the environment to coastal flooding, while fluvial flooding was taken into account in Harlech. Regardless from the source of flooding, Zone 1 classes indicate higher susceptibility, while Zone 2 lower.

All the above mentioned datasets have been developed at BGS as vector polygons at 1:50,000 scale (unless otherwise stated). These products are concerned with natural features and only examine natural geological conditions that leave an area exposed to a certain hazard. Therefore, manmade factors are typically not accounted for, except for the Compressible Ground hazard layer included in GeoSure which does consider manmade ground (e.g. landfill). An indication of natural ground stability does not necessarily mean that the location of interest will be affected by the geohazard described by the dataset. How this translates into practice is demonstrated in section 3.3.
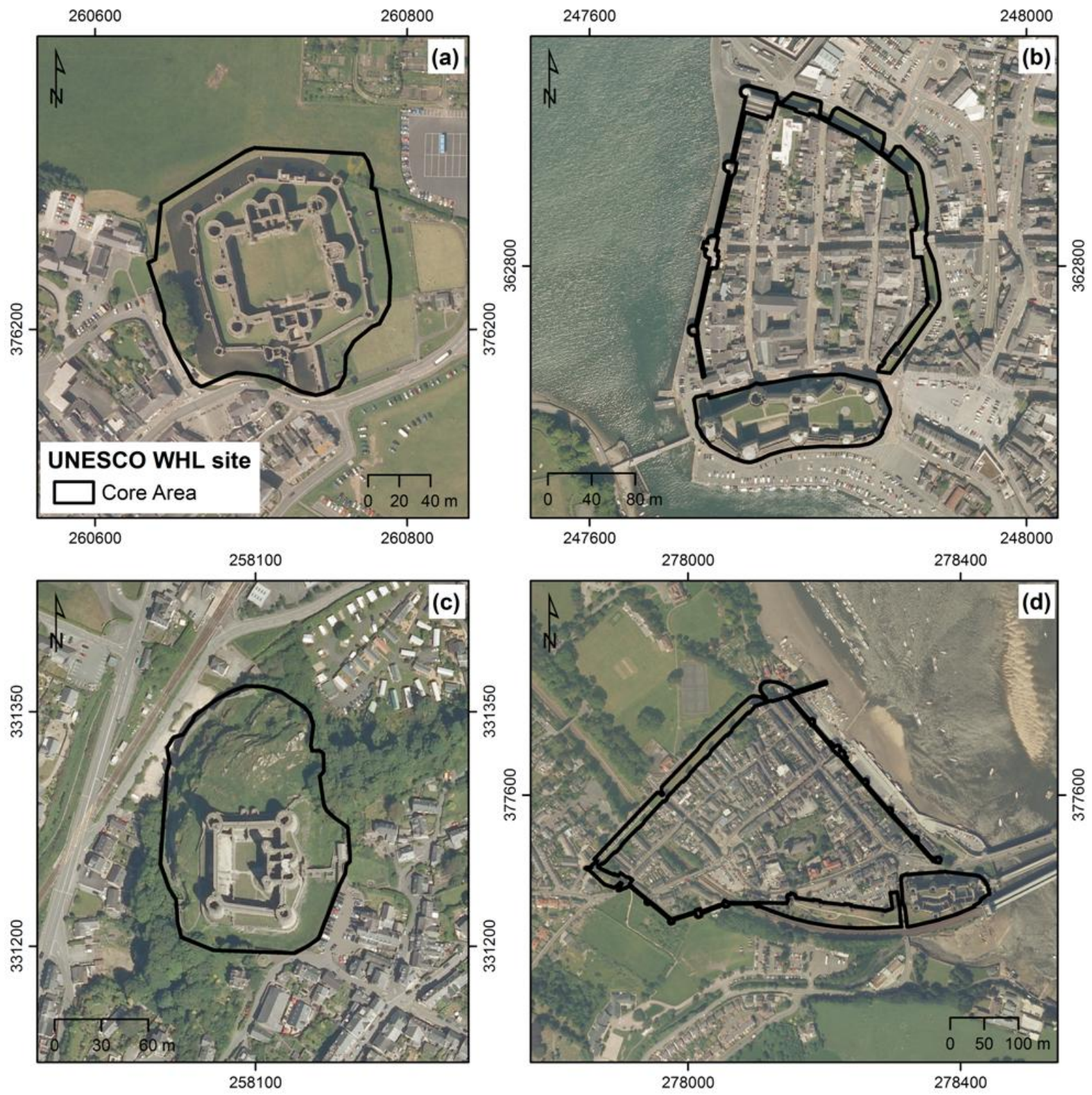

Figure 2. UNESCO WHL site of the Castles and Town Walls of King Edward in Gwynedd: (a) Beaumaris, (b) Caernarfon, (c) Harlech and (d) Conwy, overlapped onto aerial photography. Map units: British National Grid; projection: Transverse Mercator; datum: OSGB 1936 [Aerial Photography @ UKP/Getmapping Licence no UKP2006/01]. 


\subsection{Methodology}

The UNESCO WHL site in Gwynedd was used as a demonstration site to test the methodology of geohazard assessment at the scale of individual properties, as a large portion of the sites in the UK is defined by property boundaries, i.e. Core Areas, without an official Buffer Zone serving as an additional layer of protection to a World Heritage property [23]. Figure 2 illustrates the spatial extent of the core areas of the four castles. These were used as the primary spatial units to analyse the geological and geohazard datasets reported in section 3.1.

The key statistics calculated included relative percentages of the areal coverage for each geological feature or hazard class and the predominant class. For those datasets such as GeoSure that have associated a score system, the 'maximum class' as the class indicating the worst susceptibility to a certain hazard was also computed.

Since the majority of the BGS datasets used were generated at 1:50,000 scale, the geospatial datasets were also interrogated by accounting for $50 \mathrm{~m}$ buffers around the core areas. This choice conforms to the mapping resolution of the BGS datasets and allows us to deal with the associated uncertainty.

As recalled in section 2.1, Gwynedd is an exemplar of multi-property WHL site, the designation of which concerns the whole ensemble of the castle as a coherent group. Nevertheless, the variety of the geological and topographic settings where the castles sit in (see section 2.2) justifies the choice of scoring the geohazard susceptibility at the scale of the individual property instead of an overall assessment of the four castles as they were a unique distributed property.

\subsection{Hazard ratings}

Figure 3 compares the statistics based on GIF, GWF and GeoSure Landslides as they were captured by using the core areas and $50 \mathrm{~m}$ buffers around them in the castles of Caernarfon and Harlech.

In Caernarfon, the susceptibility to coastal flooding and groundwater flooding account for about $33 \%$ and $94 \%$ of the total extent of the WHL site boundaries plus the $50 \mathrm{~m}$ buffers, respectively, and therefore suggest that these hazards should be considered in the management and resilience planning of the properties. In particular, GWF shows a patchy distribution of the classed polygons. At this scale of analysis, this suggests that there might be a variation across the property of the local geological conditions predisposed to groundwater flooding.

Susceptibility to slope instability is identified in the northern sector of the core area of Harlech Castle. About $25 \%$ of the total extent of the property and $50 \mathrm{~m}$ buffer is classed "C" - i.e. slope instability may be present or anticipated and site investigation should be carried out to upscale the hazard assessment, while $6 \%$ is classed "D" - i.e. slope instability problems are probably present and might have already occurred in the past.

These figures indicate that Caernarfon and Harlech are contrasting examples of the different types of property and environmental setting that can be observed across the Gwynedd UNESCO WHL site, and that the methodological approach followed in this work enables the identification of the impact of these differences on the potential geohazards.

Beaumaris and Harlech are properties where the castles are surrounded by closed wall circuits (Figure 2a,c), while Caernarfon and Conwy castles are separated from the walls which are open along their southern sides (Figure 2b,d). These differing structural layouts add to the topographic and geographical constraints to determine the degree of exposure to flooding and slope instability hazards.

While Beaumaris and Caernarfon are located on flat coastal areas (Figure 2a,b), the wards of the Conwy castle are built at the top of an E-W oriented hill and follow the shape of the Ordovician bedrock outcrop (see section 2.2; Figure 2d). Even more hilltop is Harlech, as it rests upon part of the Harlech Dome, a 61 m-high spur of Harlech Grits Group of Cambrian age, falling sharply on the north and west (see section 2.2; Figure 2c). This latter portion of the hill is where the highest susceptibility to slope instability is found, alongside the potential of groundwater flooding to occur at surface. A finer resolution analysis might highlight what impact might be expected due to the combination of these high rates of hazard susceptibility.

The next phase of the geohazard mapping workflow developed and tested in this research will focus on the interpretation of satellite remote sensing to integrate with this baseline geohazard assessment. 


\section{Geological Indicators of} Flooding
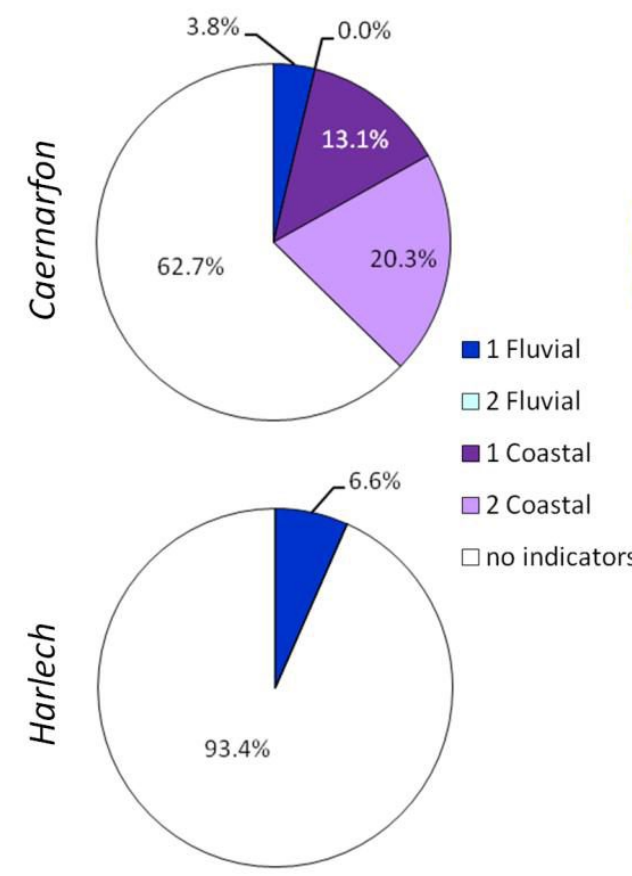

\section{Groundwater Flooding Susceptibility}
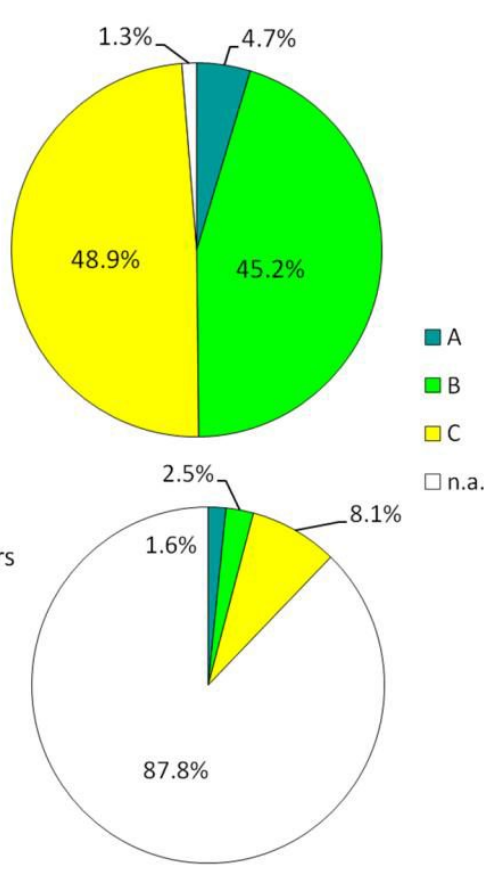

\section{Slope Instability Susceptibility}
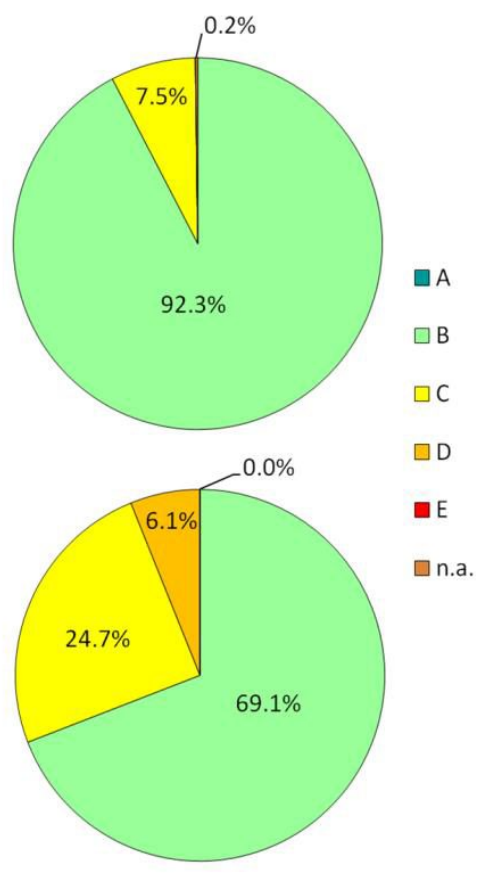

Figure 3. Pie-charts showing relative areal coverage of hazard classes within the Core Areas and $50 \mathrm{~m}$ buffer around them of the Caernarfon and Harlech castles, part of the Gwynedd UNECSO WHL site, according to the BGS datasets Geological Indicators of Flooding [14]; Susceptibility to Groundwater Flooding [15]; GeoSure Landslides layer [18]. For the legend notation refer to section 3.1.

\subsection{Satellite InSAR ground motion information}

Remotely sensed ground stability information based on space-borne radar interferometry (InSAR) will be combined in PROTHEGO with geohazard data to identify the most endangered sites across Europe.

Recent InSAR-based studies in Greater London were carried out in the framework of the European FP7-SPACE project PanGeo [24], aiming to generate and make freely accessible validated digital layers depicting areas of observed and potential ground instability for 52 of the largest towns across 27 countries within the European Union. The methodology of data integration and interpretation developed in PanGeo demonstrates how effective the combination of geological datasets and remote sensing data can be for geohazard mapping in WHL sites at the scale of individual property.

Using ERS-1/2 and ENVISAT radar imagery for the period 1992-2010 and geology field campaigns, within the administrative area of Greater London the BGS has mapped 25 geohazard areas covering a total of $\sim 650 \mathrm{~km}^{2}$ (i.e. over $40 \%$ of the administrative area) at the reference scale of $1: 10,000$ [24].

In Figure 4 the four UNESCO WHL sites of Maritime Greenwich, the Tower of London, Royal Botanic Gardens of Kew, and the Palace of Westminster and Westminster Abbey located in Greater London are overlapped onto the results of the geohazard mapping based on satellite InSAR data from the PanGeo project. Both the core area and buffer zone of Maritime Greenwich WHL are intersected by an area of natural ground movement due to compaction of Quaternary deposits of the River Thames. Anthropogenic processes due to groundwater abstraction from the Chalk aquifer were observed in Westminster, with land uplift observed in 1992-2000 and subsidence in 2002-2010, also combined with movement due to engineering works for the Jubilee Line Extension project. Groundwater management related ground motion also affected the buffer zone of the Royal Botanic gardens in Kew, whilst no geohazards were observed across the Tower of London WHL core area. 


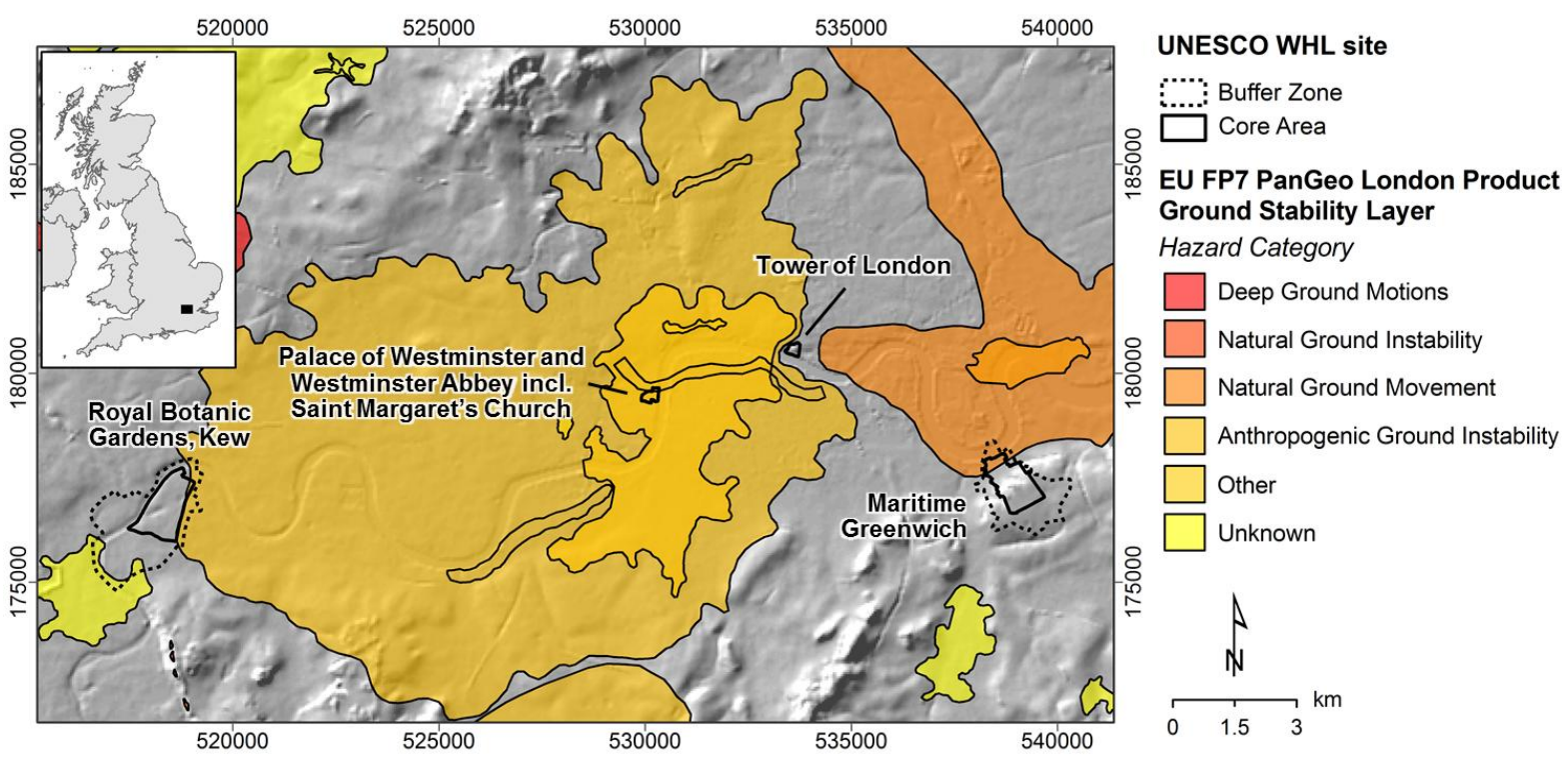

Figure 4. The four UNESCO WHL sites located in Greater London, overlapped onto natural and anthropogenic geohazard mapping from the EU FP7-SPACE PanGeo project [24] and shaded relief of NEXTMap digital terrain model at $50 \mathrm{~m}$ resolution. Map units: British National Grid; projection: Transverse Mercator; datum: OSGB 1936 [WHL site boundaries () Historic England 2015; Contains Ordnance Survey data @ C Crown copyright and database right 2015. NEXTMap® Britain elevation data (C) Intermap Technologies; PanGeo data Copyright (C) 2012. Used and/or reproduced with the permission of the rightsholders who participated in the EC FP7 PanGeo Project (262371) and European Environment Agency. Details of the rightsholders and the terms of the licence to use PanGeo project data can be found at www.pangeoproject.eu].

\section{DISCUSSION AND CONCLUSIONS}

The initial test of the methodology for geohazard mapping carried out in the UNESCO WHL site of Gwynedd and the experience of data integration and interpretation matured in the Greater London study allow us to derive two key lessons.

World heritage sites defined as individual properties require that the geohazard assessment is undertaken at least at the scale of the property boundaries, plus a buffer to allow for the spatial accuracy of the geo-dataset to be accounted for. This approach is even more applicable in those cases such as the Gwynedd castles and town walls where the UNESCO official designation includes multiple properties distributed across a whole region. Geological and topographic diversity might result in completely different geohazard scenarios that an overall assessment might smooth, with consequent risk of under-/over-estimation of the hazard ratings. Given that other important WHL sites in the UK fall within this category of heritage (e.g. Frontier of the Roman Empire), there is scope to test and implement this method of geohazard mapping across the rest of the country.

Although rural environments are those where natural hazards manifest more frequently, dense urban settings are not necessarily less susceptible, since human-induced geohazards (e.g. groundwater abstraction, surface impact of underground tunnelling) might even add onto existing natural and geological susceptibility. Therefore particular attention needs to be given when assessing geohazards affecting UNESCO WHL sites in large- to mega-cities, to account for the complexity of the local geology and its spatial interrelationship with anthropogenic factors and infrastructure. In this regard, the range of different geohazard susceptibility and impacts observed in Greater London proves the granularity and the flexibility of our method of geohazard mapping to capture variations and differential degree of exposure within the same city. 


\section{ACKNOWLEDGEMENTS}

This work is funded to the British Geological Survey (BGS) under the Arts and Humanities Research Council (AHRC) Standard Grant ref.: AH/N504361/1 (Principal Investigator: Dr F. Cigna). The manuscript is published with the permission of the Executive Director of BGS, Natural Environment Research Council (NERC). The authors would like to acknowledge Russell Lawley at BGS for his insightful comments on the manuscript. More information about the JPI$\mathrm{CH}$ Heritage Plus project PROTHEGO can be accessed at: http://www.prothego.eu. The Historic England GIS data were obtained on 14/10/2015; the most publicly available up-to-date Historic England GIS data can be obtained from http://www.historicengland.org.uk.

\section{REFERENCES}

[1] Drdácký, M., Binda, L., Herle, I., Lanza, L. G., Maxwell, I. and Pospíšil, S., "Protecting the cultural heritage from natural disasters," IP/B/CULT/IC/2006_163, Brussels, European Parliament, 120 pp. (2007).

[2] UNESCO, "Recommendation concerning the Protection at National Level, of the Cultural and Natural Heritage," 1972, accessed on 9 March 2016: http://whc.unesco.org/en/conventiontext/

[3] "PROTHEGO: PROTection of European cultural HEritage from GeO-hazards," 2016, accessed on 15 March 2016: www.prothego.eu

[4] “JPI on Cultural Heritage," 2016, accessed on 15 March 2016: http://www.jpi-culturalheritage.eu/

[5] Spizzichino, B., Margottini, C., Brustia, E., Comerci, V., Dessì, B., Guerrieri, L., Iadanza, C., Trigila A. and Vittori, E., "European UNESCO cultural heritage sites affected by geo-hazard," Fourth International Conference on Remote Sensing and Geoinformation of the Environment (RSCy2016), 4-8 April, 2016, Paphos, Cyprus, Abstract Book (2016).

[6] Cigna, F., Harrison, A., Tapete, D. and Lee, K., "Understanding geohazards in the UNESCO WHL site of the Derwent Valley Mills (UK) using geological and remote sensing data," Proceedings of the Fourth International Conference on Remote Sensing and Geoinformation of the Environment (RSCy2016), 4-8 April, 2016, Paphos, Cyprus, 10 pp. (2016).

[7] UNESCO, "World Heritage List", accessed on 9 March 2016, http://whc.unesco.org/en/list/

[8] British Geological Survey (BGS), "DiGMapGB-625," 2016, accessed on 15 March 2016: http://www.bgs.ac.uk/products/digitalmaps/DiGMapGB_625.html

[9] British Geological Survey (BGS), "Make-a-map," 2016, accessed on 18 March 2016: http://www.bgs.ac.uk/discoveringGeology/geologyOfBritain/makeamap/map.html

[10] Intermap, "Intermap Product Handbook \& Quick Start Guide. Edit Rules Edition, v.4.4.3," Intermap Technologies Inc., 157 pp. (2015).

[11] Smith, A., "Digital Geological Map of Great Britain, information notes, 2013," BGS Open Report OR/13/007, Nottingham, UK, 54 pp. (2013).

[12] Tye, A. M., Entwisle, D. E. and Newsham, R., "User Guide for the British Geological Survey Corrosivity (Ferrous) dataset," BGS Open Report OR/11/023, Nottingham, UK, 17 pp. (2011).

[13] Entwisle, D., Lawley, R., Tye, A. and Turner P., "User Guide for DiGMapPlus Engineering Properties: Sulfate and Sulfide Potential," BGS Open Report OR/15/054, Nottingham, UK, 15 pp. (2015).

[14] Booth, K. and Wildman, G., "Geological Indicators of Flooding: User Guidance Notes, 2010," BGS Open Report OR/10/064, Nottingham, UK, 10 pp. (2010).

[15] British Geological Survey (BGS), "BGS Data Products. Susceptibility to groundwater flooding. Explanatory notes for users," 4 pp. (2016).

[16] Booth, K. A., Diaz-Doce, D., Harrison, M. and Wildman, G., "User Guide for the British Geological Survey GeoSure dataset,” BGS Internal Report OR/10/066, 17 pp. (2010).

[17] Walsby, J. C., "Geosure: a bridge between geology and decision making," In: Liverman et al. (eds), Communicating Environmental Geoscience. Geological Society, London, UK, 81-87 (2008). 
[18] Lee, K. A. and Diaz-Doce. D., "User Guide for the British Geological Survey GeoSure dataset," BGS Internal Report OR/14/012, 17 pp. (2014).

[19] Harrison, A. M., Plim, J. F. M., Harrison, M., Jones, L. D. and Culshaw, M. G., "The relationship between shrink-swell occurrence and climate in south-east England," Proc. Geologists' Assoc. 123(4), 556-575 (2012).

[20] Gibson, A. D., Culshaw, M. G., Dashwood, C. and Pennington, C. V. L., "Landslide management in the UKthe problem of managing hazards in a 'low-risk' environment," Landslides 10(5), 599-610 (2013).

[21] Farrant, A. R. and Cooper, A. H., "Karst geohazards in the UK: the use of digital data for hazard management," Quarterly Journal of Engineering Geology and Hydrogeology 41(3), 339-356 (2008).

[22] Cooper, A. H., Farrant, A. R. and Price, S. J., "The use of karst geomorphology for planning, hazard avoidance and development in Great Britain," Geomorphology 134(1-2), 118-131 (2011).

[23] UNESCO, "International Expert meeting on World Heritage and buffer zones," 2008, accessed on 18 March 2016: http://whc.unesco.org/en/events/473/

[24] Cigna, F., Jordan, H., Bateson, L., McCormack, H. and Roberts, C., "Natural and anthropogenic geohazards in Greater London observed from geological and ERS-1/2 and ENVISAT Persistent Scatterers ground motion data: results from the EC FP7-SPACE PanGeo project," Pure Appl. Geophysics 172(11), 2965-2995 (2015). 